\title{
PENGARUH BACAAN MUROTTAL AL-QUR'AN YANG DIPERDENGARKAN PADA PASIEN STROKE ISKEMIK AKUT TERHADAP LUARAN KLINIS
}

\author{
THE EFFECT OF HOLY QUR'AN HEARING ON CLINICAL OUTCOMES IN \\ ACUTE ISCHEMIC STROKE
}

Susi Ifati, * Dodik Tugasworo, * Dwi Pudjonarko*

\section{ABSTRACT}

Introduction: Qur'an recitation has a high spiritual and religious value and effect to Islam believer, and also has beautiful and regular tone, so that it is believed to be useful to cure various diseases. Depression and anxiety are common, and add to worsening outcomes of stroke. There was spiritual correlation between decreased emotional distress and depression associated with poor outcome of stroke. Qur'an recitation could be used as spiritual relaxation technique, thus improve the effect of mental health.

Aims: To determine effect of Qur'an recitation audio on anxiety, depression and National Institute of Health Stroke Scale (NIHSS) in acute ischemic stroke in Medical Faculty of Diponegoro University/dr. Kariadi Hospital, Semarang, Central Java Indonesia.

Method: This was an intended to treat research with randomized pretest-posttest with control group design. Subjects were acute ischemic stroke patients with onset less than 72 hours, divided into treatment and control groups. Treatment was carried out for 7 days by playing Juz 'Amma Qur'an recitation through headphone twice a day for 30 minutes at 06.00 am and 06.00 pm. Demographic data, risk factors, and Hospital Anxiety and Depression Scale (HADS) and NIHSS before and after treatment were assessed. The correlation of HADS and NIHSS between treatment and control were analyzed with Chi-square/Fisher test. Multivariate analysis was used to analyzed other factors affecting clinical outcomes.

Result: Forty subjects were randomized into treatment or control groups. There was significant correlation between listening Juz 'Amma Qur'an recitation with improvement of anxiety HADS and NIHSS. There was no correlation with improvement of depression HADS. Logistic regression analysis showed improvement of NIHSS after listening Juz 'Amma Qur'an recitation.

Discussion: Listening to the Qur'an recitation improved anxiety symptoms, improved clinical outcomes by 9.025 times compared to controls in acute ischemic stroke, thus can be considered to support the recovery of stroke patients.

Keywords: Acute ischemic stroke, HADS, NIHSS, Qur'an recitation

\section{ABSTRAK}

Pendahuluan: Bacaan Al-Qur'an memiliki nilai spiritualitas dan religiositas yang tinggi serta memberikan efek ketenangan selain nadanya indah dan teratur, sehingga dapat digunakan untuk penyembuhan berbagai penyakit. Depresi maupun ansietas sering terjadi pada stroke yang menambah perburukan luaran. Terdapat hubungan spiritual pada penurunan ansietas dan depresi yang dihubungkan dengan luaran stroke yang buruk. Bacaan Al-Qur'an dapat digunakan sebagai teknik relaksasi spiritual sehingga didapatkan efek meningkatkan kesehatan mental.

Tujuan: Untuk mengetahui pengaruh murottal Al-Qur'an yang diperdengarkan pada pasien stroke iskemik akut terhadap luaran klinis neurologis menggunakan skor National Institute of Health Stroke Scale (NIHSS), gangguan depresi dan ansietas di Fakultas Kedokteran Universitas Diponegoro/RSUP dr. Kariadi, Semarang, Jawa Tengah, Indonesia.

Metode: Penelitian ini merupakan penelitian perlakuan randomized pretest-posttest control group design. Subjek adalah pasien stroke iskemik akut awitan kurang 72 jam, dibagi menjadi kelompok perlakuan dan kontrol. Perlakuan dilaksanakan 7 hari dengan memperdengarkan murottal Al-Qur'an Juz 'Amma melalui headphone sehari 2 kali, durasi 30 menit pukul 06.00 dan 16.00. Data yang diambil meliputi data demografi, faktor risiko stroke serta penilaian Hospital Anxiety and Depression Scale (HADS), dan NIHSS sebelum dan setelah perlakuan. Pengaruh perlakuan terhadap HADS, NIHSS menggunakan uji Chi-square/Fisher. Faktor-faktor lain yang berpengaruh pada luaran klinis juga dianalisis secara multivariat.

Hasil: Sebanyak 40 subjek dilakukan random alokasi sebagai kelompok perlakuan berjumlah 20 subjek dan kelompok kontrol berjumlah 20 subjek. Terdapat hubungan bermakna antara memperdengarkan murottal Al-Qur'an dengan perbaikan HADS ansietas, dan perbaikan NIHSS. Tidak terdapat hubungan antara memperdengarkan murottal Al-Qur'an dan perbaikan HADS depresi. Analisis logistik regresi menunjukkan, memperdengarkan murottal Al-Qur'an berpengaruh pada perbaikan NIHSS pasien stroke iskemik akut.

Diskusi: Memperdengarkan murottal Al-Qur'an memperbaiki gejala ansietas, memperbaiki luaran klinis sebesar 9,025 kali dibanding kontrol pada stroke iskemik akut sehingga dapat dipertimbangkan untuk menunjang pemulihan pasien stroke.

Kata kunci: Murottal Al-Qur'an, NIHSS, skor HADS, stroke iskemik akut

*SMF Neurologi FK Universitas Diponegoro/RSUP dr. Kariadi, Semarang. Korespondensi: fatisusi@gmail.com. 


\section{PENDAHULUAN}

Indonesia merupakan negara dengan mayoritas penduduknya beragama Islam yang berkeyakinan bahwa bacaan Al-Qur'an dapat memberikan efek ketenangan sehingga dapat digunakan untuk penyembuhan penyakit. Bacaan murottal Al-Qur'an adalah salah satu cara atau metode dalam membaca Al-Qur'an. Kata ini berasal dari bahasa arab "tartil" yang berarti perlahan-lahan atau tidak tergesa-gesa sehingga membaca Al-Qur'an secara murottal berarti membaca secara perlahan-lahan atau tidak tergesagesa sesuai kaidah cara membaca Al-Qur'an yang benar atau sesuai kaidah tajwid. Bacaan murottal Al-Qur'an memiliki kelebihan dibandingkan dengan mendengarkan musik karena bacaan Al-Qur'an memiliki nilai spiritualitas dan religiositas (S/R) yang tinggi, selain nadanya yang indah dan teratur. ${ }^{1}$

Istilah spiritual berkaitan dengan hubungan transenden yang menjawab pertanyaan-pertanyaan tentang makna kehidupan, bahwa ada sesuatu lebih dari apa yang bisa dilihat atau dipahami, adanya kekuatan di luar manusia (Tuhan), sehingga bisa disimpulkan spiritual merupakan keyakinan seseorang adanya Tuhan. Sedangkan religius merupakan aplikasi dari spiritual yang diterapkan dalam kehidupan sehari-hari, yang tertuang dalam peraturan kehidupan dalam suatu agama tertentu. ${ }^{2-4}$ Spiritualitas dan religius berhubungan dengan pola yang spesifik terhadap respons kardiovaskular seperti penurunan tekanan darah, $C$-reactive protein dan respons kortisol pada jalur aksis HypothalamicPituitary-Adrenal (HPA) sebagai efek dari stres. ${ }^{2-5}$ Bacaan Al-Qur'an dapat digunakan sebagai teknik relaksasi spiritual untuk mendapatkan ketenangan jiwa yang erat kaitannya dengan proses relaksasi tubuh, sehingga didapatkan efek meningkatkan kesehatan mental setelah mendengarkan Al-Qur'an. ${ }^{6-7}$ Banyak penelitian yang menilai efektivitas murottal Al-Qur'an sebagai terapi tambahan pada gangguan fisik maupun psikis. Diantaranya meningkatkan angka harapan hidup pada pasien kanker, penurunan depresi, menurunkan kesedihan, ketenangan jiwa, kecemasan, menurunkan tekanan darah pada usia lanjut, membantu pengobatan pada pasien insomnia, mengurangi rasa nyeri dan meningkatkan angka harapan hidup pada pasien keganasan. ${ }^{8-13}$

Stroke merupakan salah satu kelainan neurologis yang menjadi penyebab utama disabilitas kronis. Diperkirakan satu dari tiga kasus stroke akan berakibat kematian, dan satu dari tiga kasus stroke akan berakibat disabilitas. Disabilitas meliputi gangguan fisik, kognitif, emosional, dan sosial. World Health Organization (WHO) memprediksi angka disabilitas akan meningkat dari 38 juta pada tahun 1990 menjadi 61 juta pada tahun 2020. ${ }^{14-16}$

Stroke iskemik akut bertindak sebagai stresor yang menstimulasi aksis HPA, yang menghasilkan kenaikan hormon glukokortikoid. Neidert dalam penelitiannya menemukan kadar kortisol yang tinggi pada pasien stroke dengan luaran fungsional yang buruk atau bahkan kematian menunjukkan tingginya tingkat stres pada pasien tersebut. Pada pasien-pasien dengan stroke akut, konsentrasi adrenocorticotropic hormone (ACTH) dan kortisol yang tinggi atau terlalu rendah dihubungkan dengan daerah infark yang lebih besar, luaran fungsional yang lebih buruk, dan peningkatan kematian. Dari berbagai penelitian menunjukkan bahwa kortisol bersifat neurotoksik sehingga aktivasi aksis HPA akan menambah tingkat keparahan stroke iskemik. Pasien dengan peningkatan kortisol mungkin memiliki respons peradangan yang kuat, dengan peningkatan suhu tubuh, fibrinogen, jumlah sel darah putih, tromboglobulin, dan konsentrasi IL-6. Konsentrasi kortisol yang tinggi pada beberapa penelitian, tetapi tidak di penelitian lainnya, juga telah dihubungkan dengan ekspresi katekolamin yang lebih tinggi, dan infark lobus frontal atau infark insular. Peningkatan aktivitas aksis HPA akan mengakibatkan efek yang luas di tubuh dan dapat berperan terhadap perubahan di energi, tidur, mood, kognitif, berat badan, dan kardiovaskular. Kadar kortisol yang meningkat berhubungan dengan ukuran lesi, defisit neurologis, dan sindrom klinis stroke yang menggambarkan derajat keparahan dari stroke. Pasien stroke dengan kadar kortisol yang tinggi menunjukkan risiko terjadinya gangguan jantung dan berkembangnya infeksi. Hal ini berhubungan dengan disregulasi dari 
imun sebagai akibat gangguan neuroendokrin yang terjadi setelah stroke. ${ }^{17-18}$

Gangguan emosional berupa depresi maupun ansietas sering terjadi pada stroke dan memperburuk luaran. Sekitar 30\% pasien stroke akan mengalami gangguan emosional berupa depresi, ansietas, apatis maupun kelelahan. Terdapat hubungan antara spiritual dengan penurunan distres emosional setelah stroke. Spiritualisasi dapat mengurangi depresi, dimana depresi dihubungkan dengan luaran stroke yang buruk. ${ }^{2,19-20}$

Skala National Institute of Health Stroke Scale (NIHSS) merupakan skala yang digunakan untuk mengukur derajat perburukan neurologis kasus stroke dan merupakan salah satu instrumen pengukuran klinis yang dapat dipercaya. Banyak penelitian telah menunjukkan bahwa skor NIHSS pada saat awal merupakan prediktor yang sangat kuat untuk menilai luaran stroke iskemik setelah 7 hari dan 3 bulan. Terdapat beberapa faktor yang berperan penting pada stroke iskemik fase akut yang dapat digunakan untuk memperkirakan luaran stroke meliputi usia, keparahan stroke, status fungsional sebelum terjadi stroke seperti kondisi komorbid, ganguan kognitif, dan kesadaran yang dapat memperburuk luaran klinis pasien. Prediktor angka kematian jangka panjang pada stroke meliputi hipertensi, merokok, dan DM..$^{21-22}$

\section{TUJUAN}

Penelitian ini bertujuan untuk mengetahui pengaruh murottal Al-Qur'an yang diperdengarkan pada pasien stroke iskemik akut terhadap luaran klinis neurologis menggunakan skor NIHSS, dengan menganalisis hubungan perubahan gangguan depresi dan cemas serta faktor-faktor lain yang berhubungan dengan perubahan skor NIHSS.

\section{METODE}

Penelitian ini dilakukan dengan randomized pretest-posttest control group design. Subjek penelitian adalah pasien stroke iskemik akut yang dirawat di Instalasi Rawat Inap RSUP dr. Kariadi, Semarang, Jawa Tengah, Indonesia dari bulan Mei 2017-Februari 2018, dengan kriteria inklusi pasien stroke iskemik akut, yang datang di rumah sakit dengan awitan kurang dari 72 jam, adanya oklusi/ sumbatan pada sirkulasi anterior atau campuran, sadar penuh/GCS 15 , berusia $\geq 18$ tahun, skor NIHSS $\geq 5$, stroke pertama kali, beragama Islam, dapat mendengarkan suara/bunyi murottal Al-Qur'an melalui headphone. Kriteria eksklusi meliputi gagal ginjal akut atau kronis, afasia, infeksi kronis atau sepsis, dan kelainan hati.

Data primer diperoleh dari pasien stroke iskemik akut menggunakan kuesioner yang terdiri atas data demografi (usia, jenis kelamin, alamat, pekerjaan, status perkawinan, pendidikan), faktor risiko (perokok, DM, hipertensi, penyakit jantung), pemeriksaan fisik, pemeriksaan laboratorium berupa sampel darah vena (gula darah puasa, profil lipid), pemeriksaan Multislice Computerized Tomography (MSCT) kepala, pemeriksaan EKG serta skor depresi dan ansietas dengan Hospital Anxiety and Depression Scale (HADS) sebelum dan setelah perlakuan dan penilaian klinis neurologis dengan NIHSS sebelum dan setelah perlakuan. Data berskala interval dan rasio diuji normalitasnya dengan Saphiro-Wilk. Analisis bivariat dilakukan dengan uji Chi-square atau uji Fisher untuk mengetahui hubungan perlakuan berupa murottal Al-Qur'an yang diperdengarkan terhadap skor HADS dan NIHSS yang sudah dikategorisasi, serta untuk mengetahui hubungan faktor-faktor risiko dengan perbaikan skor NIHSS yang sudah dikategori. Hasil analisis bivariat dengan $\mathrm{p}<0,25$ dianalisis lebih lanjut dengan uji multivariat regresi logistik untuk mengetahui variabel yang berpengaruh terhadap perubahan skor NIHSS yang sudah dikategori.

Hospital Anxiety and Depression Scale terdiri dari 14 pernyataan yang dibagi menjadi 2 subskala, yaitu untuk menilai ansietas ( 7 pernyataan) dan depresi (7 pernyataan). Titik potong yang direkomendasikan adalah: lebih dari 16 menyatakan kasus berat, 11-15 merupakan kasus sedang, 8-10 merupakan kasus ringan, dan kurang dari 7 bukan merupakan suatu kasus ansietas atau depresi.

Pasien yang masuk dalam kriteria inklusi diminta bukti persetujuan secara tertulis dengan membubuhkan tanda tangan pada lembaran informed consent. Pada kelompok perlakuan, selain terapi standar, pasien diperdengarkan murottal Juz 'Amma 
Tabel 1. Karakteristik Subjek

\begin{tabular}{|c|c|c|c|c|}
\hline \multirow[b]{2}{*}{ Karakteristik } & \multicolumn{2}{|c|}{ Kelompok Perlakuan $(n=21)$} & \multicolumn{2}{|c|}{ Kelompok Kontrol $(n=21)$} \\
\hline & n $(\%)$ & $\begin{array}{c}\text { Rerata } \pm \text { SB } \\
\text { Median (Min-Maks) }\end{array}$ & n $(\%)$ & $\begin{array}{c}\text { Rerata } \pm \text { SB } \\
\text { Median (Min-Maks) }\end{array}$ \\
\hline Umur & & $56,75 \pm 9,13$ & & $56,95 \pm 8,91$ \\
\hline \multicolumn{5}{|l|}{ Jenis kelamin } \\
\hline - Laki-laki & $9(45)$ & & $13(65)$ & \\
\hline - Perempuan & $11(55)$ & & $7(35)$ & \\
\hline \multicolumn{5}{|l|}{ Status perkawinan } \\
\hline - Kawin & $20(100)$ & & $18(90)$ & \\
\hline - Janda & $0(0)$ & & $2(10)$ & \\
\hline \multicolumn{5}{|l|}{ Riwayat hipertensi } \\
\hline - Ya & $16(80)$ & & $20(100)$ & \\
\hline - Tidak & $4(20)$ & & $0(0)$ & \\
\hline \multicolumn{5}{|l|}{ Riwayat DM } \\
\hline - Ya & $3(15)$ & & $4(20)$ & \\
\hline - Tidak & $17(85)$ & & $16(80)$ & \\
\hline \multicolumn{5}{|c|}{ Riwayat penyakit jantung } \\
\hline - Ya & $2(10)$ & & $2(10)$ & \\
\hline - Tidak & $18(90)$ & & $18(90)$ & \\
\hline \multicolumn{5}{|l|}{ Onset } \\
\hline$\bullet<5$ jam & $4(20)$ & & $2(10)$ & \\
\hline$\bullet>5 \mathrm{jam}$ & $16(80)$ & & $18(90)$ & \\
\hline \multicolumn{5}{|l|}{ Lokasi kelainan } \\
\hline - Sirkulasi anterior & $15(75)$ & & $17(85)$ & \\
\hline - Campuran & $5(25)$ & & $3(15)$ & \\
\hline \multicolumn{5}{|l|}{ Hipertensi } \\
\hline - Ya & $16(80)$ & & $20(100)$ & \\
\hline - Tidak & $4(20)$ & & $0(0)$ & \\
\hline \multicolumn{5}{|l|}{ DM } \\
\hline - DM & $8(40)$ & & $6(30)$ & \\
\hline - Tidak DM & $12(60)$ & & $14(70)$ & \\
\hline \multicolumn{5}{|l|}{ Dislipidemia } \\
\hline - Dislipidemia & $14(70)$ & & $6(30)$ & \\
\hline - Tidak dislipidemia & $6(30)$ & & $14(70)$ & \\
\hline \multicolumn{5}{|l|}{ Merokok } \\
\hline - Merokok & $7(35)$ & & $12(60)$ & \\
\hline - Tidak merokok & $13(65)$ & & $8(40)$ & \\
\hline \multicolumn{5}{|l|}{ IMT } \\
\hline - Tidak obesitas & $10(50)$ & & $12(60)$ & \\
\hline - Obesitas & $10(50)$ & & $8(40)$ & \\
\hline
\end{tabular}

SB: simpang baku; Min-Maks: minimal-maksimal. DM: diabetes melitus; IMT: indeks massa tubuh. 
oleh Idris Al Hasyimi melalui headphone sehari 2 kali dilaksanakan selama fase akut stroke iskemik selama 7 hari, dengan durasi 30 menit pada pagi pukul 06.00 dan sore hari pukul 16.00. Pada kelompok kontrol pasien diberikan terapi standar untuk stroke iskemik akut tanpa disertai perlakuan berupa pemberian murottal Al-Qur'an. Penelitian ini mendapatkan ethical clearance dari RSUP dr. Kariadi, Semarang.

Tabel 2. Tabel Perbedaan HADS Ansietas, Depresi, dan NIHSS antara Kelompok Perlakuan dan Kontrol

\begin{tabular}{|c|c|c|c|c|c|}
\hline \multirow{3}{*}{ Variabel } & \multicolumn{4}{|c|}{ Kelompok } & \multirow{3}{*}{$\mathbf{p}$} \\
\hline & \multicolumn{2}{|c|}{ Perlakuan $(n=20)$} & \multicolumn{2}{|c|}{ Kontrol $(\mathrm{n}=\mathbf{2 0})$} & \\
\hline & $\mathbf{n}(\%)$ & $\begin{array}{c}\text { Rerata } \pm \text { SB } \\
\text { Median (Min-Maks) }\end{array}$ & n $(\%)$ & $\begin{array}{c}\text { Rerata } \pm \text { SB } \\
\text { Median (Min-Maks) }\end{array}$ & \\
\hline HADS (A) saat datang & & $9,85 \pm 2,815$ & & $8,15 \pm 2,739$ & $0,060^{\S *}$ \\
\hline - Normal & $4(20)$ & & $8(40)$ & & $0,331^{£}$ \\
\hline - Kasus ringan & $9(45)$ & & $8(40)$ & & \\
\hline - Kasus sedang & $7(35)$ & & $4(20)$ & & \\
\hline $\begin{array}{l}\text { HADS (A) setelah } \\
\text { perlakuan }\end{array}$ & & $5,35 \pm 2,084$ & & $5,35 \pm 2,852$ & $1,000^{\S}$ \\
\hline - Normal & $19(95)$ & & $15(75)$ & & $0,102^{\ddagger}$ \\
\hline - Kasus ringan & $0(0)$ & & $5(25)$ & & \\
\hline - Kasus sedang & $1(5)$ & & $0(0)$ & & \\
\hline$\triangle$ HADS (A) & & $4,50 \pm 2,48$ & & $2(0-7)$ & $0,020^{* *}$ \\
\hline - Perbaikan & $20(100)$ & & $15(75)$ & & $0,047^{¥ *}$ \\
\hline - Tidak perbaikan & $0(0)$ & & $5(25)$ & & \\
\hline HADS (D) saat datang & & $8,20 \pm 2,913$ & & $8(3-10)$ & $0,520^{\ddagger}$ \\
\hline - Normal & $6(30)$ & & $8(40)$ & & $0,241^{\ddagger}$ \\
\hline - Kasus ringan & $11(55)$ & & $12(60)$ & & \\
\hline - Kasus sedang & $3(15)$ & & $0(0)$ & & \\
\hline $\begin{array}{l}\text { HADS (D) setelah } \\
\text { perlakuan }\end{array}$ & & $4,25 \pm 2,173$ & & $4,95 \pm 2,704$ & $0,418^{\ddagger}$ \\
\hline - Normal & $18(90)$ & & $15(75)$ & & $0,407^{¥}$ \\
\hline - Kasus ringan & $2(10)$ & & $5(25)$ & & \\
\hline$\Delta$ HADS (D) & & $3(0-13)$ & & $2(0-5)$ & $0,234^{\ddagger}$ \\
\hline - Perbaikan & $18(90)$ & & $15(75)$ & & $0,407^{¥}$ \\
\hline - Tetap & $2(10)$ & & $5(25)$ & & \\
\hline NIHSS saat datang & & $7,85 \pm 1,927$ & & $7(5-20)$ & 0,784 \\
\hline - NIHSS ringan & $0(0)$ & & $0(0)$ & & \\
\hline - NIHSS sedang & $100(100)$ & & $100(100)$ & & \\
\hline $\begin{array}{l}\text { NIHSS setelah } \\
\text { perlakuan }\end{array}$ & & $4(2-6)$ & & $5(2-14)$ & 0,099 \\
\hline - NIHSS ringan & $17(85)$ & & $9(45)$ & & $0,204^{£}$ \\
\hline - NIHSS sedang & $3(15)$ & & $11(55)$ & & \\
\hline$\Delta$ NIHSS & & $4(0-6)$ & & $3,5(0-6)$ & $0,019 * *$ \\
\hline - Perbaikan & $17(85)$ & & $10(90)$ & & $0,018^{£ *}$ \\
\hline - Tidak perbaikan & $3(15)$ & & $10(10)$ & & \\
\hline
\end{tabular}

*Signifikan; *Fisher's exact; ${ }^{\circledR}$ Pearson Chi-square; ${ }^{\ddagger}$ Mann-Whitney ${ }^{\text {Paired t; }}{ }^{\S}$ Uji t; Skor HADS $>16$ : kasus berat, 11-15: kasus sedang, 8-10: kasus ringan, $<7$ : normal; Skor NIHSS $\geq 25$ : defisit neurologis sangat berat, skor 15-24: defisit neurologis berat, skor 5-14: defisit neurologis sedang, dan skor $<5$ defisit neurologis ringan; A: Ansietas; D: Depresi; HADS: Hospital Anxiety and Depression Scale; NIHSS: National Institute of Health Stroke Scale. 


\section{HASIL}

Penelitian ini melibatkan 40 subjek pasien stroke iskemik akut yang terdiri dari 20 subjek kelompok perlakuan dan 20 subjek kelompok kontrol. Distribusi subjek berdasarkan karakteristik individu dapat dilihat pada Tabel 1. Tidak ada perbedaan yang bermakna pada karakteristik subjek antara kelompok perlakuan dan kelompok kontrol.

Tabel 2 menunjukkan perbedaan variabelvariabel antara kelompok perlakuan dan kontrol. Semua kelompok perlakuan yang sebelumnya mengalami ansietas menjadi tidak ansietas. Derajat depresi pada kelompok perlakuan mengalami perbaikan menjadi tidak depresi pada 90\% sampel, dan sisanya mengalami perbaikan menjadi depresi ringan. Jumlah ini lebih besar dibandingkan kelompok kontrol sebesar $75 \%$ untuk skor ansietas maupun depresi. Terdapat hubungan yang bermakna antara perbaikan skor HADS ansietas dan perlakuan memperdengarkan murottal Al-Qur'an $(\mathrm{p}=0,02)$. Tidak terdapat hubungan antara HADS depresi dan perlakuan memperdengarkan murottal Al-Qur'an $(\mathrm{p}=0,407)$.

Pada kelompok perlakuan didapatkan perbaikan skor NIHSS yang lebih besar dibandingkan kontrol. Terdapat perbedaan rerata delta skor NIHSS yang bermakna antara subjek kelompok perlakuan dan kelompok kontrol $(\mathrm{p}=0,019)$.

Tabel 3. Analisis Hubungan Perubahan Skor HADS Ansietas dan Depresi dengan Perubahan Skor NIHSS pada Pasien Stroke Iskemik Akut dengan Menggunakan Uji Fisher's

\begin{tabular}{|c|c|c|c|}
\hline \multirow{4}{*}{ Variabel } & \multicolumn{2}{|c|}{ Analisis Bivariat } & \multirow{4}{*}{$\mathbf{p}$} \\
\hline & \multicolumn{2}{|c|}{$\begin{array}{c}\text { Perubahan Kategori } \\
\text { NIHSS }\end{array}$} & \\
\hline & Membaik & Tetap & \\
\hline & $\%$ & $\%$ & \\
\hline
\end{tabular}

\section{HADS ansietas}

$\begin{array}{llllll}\text { - Membaik } & 26 & 74,3 & 9 & 25,7 & 0,031^{* *}\end{array}$

$\begin{array}{lllll}\text { - Tetap } & 1 & 20 & 4 & 80\end{array}$

\section{HADS depresi}

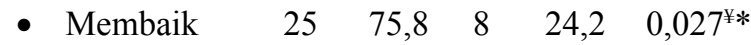

- Tetap $\quad 2 \quad 28,6 \quad 5 \quad 71,4$

*Signifikan; ${ }^{*}$ Fisher's exact; ${ }^{£}$ Pearson Chi-square. HADS: Hospital Anxiety and Depression Scale; NIHSS: National Institute of Health Stroke Scale.
Tabel 3 menunjukkan terdapat hubungan yang bermakna antara perubahan skor HADS ansietas dan depresi dengan perubahan skor NIHSS pada pasien stroke iskemik akut kelompok perlakuan dan kelompok kontrol.

Analisis bivariat dilakukan pada umur, jenis kelamin, hipertensi, DM, dislipidemia, merokok, IMT, skor HADS ansietas depresi, kadar kortisol serum dan perlakuan berupa murottal Al-Qur' an yang diperdengarkan terhadap perubahan skor NIHSS pasien stroke iskemik akut (Tabel 4). Hasil analisis bivariat menunjukkan bahwa terdapat hubungan antara perubahan HADS ansietas, perubahan HADS depresi, dan pemberian murottal Al-Qur'an dengan perubahan skor NIHSS pasien stroke iskemik akut $(p=0,031 ; p=0,027 ; p=0,018$ secara berurutan).

Tabel 4 merupakan analisis multivariat yang menunjukkan bahwa secara statistik variabel yang berpengaruh terhadap perbaikan skor NIHSS pasien stroke iskemik akut adalah perlakuan memperdengarkan murottal Al-Qur'an, dengan kekuatan hubungan yaitu $\mathrm{RO}=9,025 ; \mathrm{p}=0,011$.

\section{PEMBAHASAN}

Faktor-faktor yang memengaruhi luaran klinis neurologis pada stroke iskemik akut meliputi usia, jenis kelamin, hipertensi, diabetes melitus (DM), dislipidemia, merokok, IMT (Indeks Massa Tubuh), letak dan tipe lesinya, serta infeksi. Pada penelitian ini, umur $<65$ tahun merupakan faktor risiko terhadap perbaikan skor NIHSS sebesar 70,1 kali pada pasien stroke iskemik akut, sejalan dengan penelitian oleh Giovarsi yang meneliti 1.057 pasien stroke iskemik akut yang pertama kali meneliti faktor-faktor yang dapat digunakan untuk memprediksi keparahan stroke dengan NIHSS, dengan regresi logistik didapatkan umur sangat tua ( $\geq 85$ tahun) merupakan prediktor independen terhadap keparahan stroke yang dinilai dengan NIHSS $(\mathrm{RO}=2,98 ; \mathrm{p}=0,0001)$.

Pada penelitian ini didapatkan hubungan yang bermakna antara perbaikan skor HADS ansietas dan perlakuan memperdengarkan murottal Al-Qur'an. Tidak terdapat hubungan yang bermakna antara perbaikan HADS depresi dan perlakuan memperdengarkan murottal Al-Qur'an ( $\mathrm{p}=0,020 ; \mathrm{p}=0,407)$. 
Tabel 4. Hasil Analisis Regresi Logistik Faktor-faktor yang Berpengaruh terhadap Perubahan Skor NIHSS Pasien Stroke Iskemik Akut

\begin{tabular}{|c|c|c|c|c|c|c|c|c|c|c|c|c|}
\hline \multirow{4}{*}{ Faktor Risiko } & \multirow{2}{*}{\multicolumn{4}{|c|}{$\begin{array}{c}\text { Analisis Bivariat } \\
\text { Perubahan Kategori NIHSS } \\
\end{array}$}} & \multicolumn{8}{|c|}{ Analisis Multivariat } \\
\hline & & & & & \multirow{3}{*}{ p } & \multirow{3}{*}{ RO } & \multirow{2}{*}{\multicolumn{2}{|c|}{ IK 95\% }} & \multirow{3}{*}{$\mathbf{p}$} & \multirow{3}{*}{ RO } & \multirow{2}{*}{\multicolumn{2}{|c|}{ IK 95\% }} \\
\hline & \multicolumn{2}{|c|}{ Perbaikan } & \multicolumn{2}{|c|}{ Tidak Perbaikan } & & & & & & & & \\
\hline & $\mathrm{n}$ & $\%$ & $\mathbf{n}$ & $\%$ & & & Min & Max & & & Min & Max \\
\hline \multicolumn{13}{|c|}{ Kelompok penelitian } \\
\hline - Murottal $(+)$ & 17 & 85 & 3 & 15 & $0,018^{£}$ & 5,57 & 1,25 & 25,6 & 0,011 & 9,03 & 1,64 & 49,66 \\
\hline - Murottal (-) & 10 & 50 & 10 & 50 & & & & & & & & \\
\hline \multicolumn{13}{|l|}{ Umur } \\
\hline - $\leq 65$ tahun & 25 & 73,3 & 9 & 26,5 & $0,075^{¥}$ & 5,56 & 0,86 & 35,7 & 0,070 & 7,7 & 0,85 & 70,1 \\
\hline - $>65$ tahun & 2 & 26,3 & 4 & 66,7 & & & & & & & & \\
\hline \multicolumn{13}{|l|}{ Merokok } \\
\hline - Tidak perokok & 17 & 81 & 4 & 19 & $0,056^{£}$ & 0,26 & 0,06 & 1,07 & 0,836 & 0,81 & 0,11 & 5,84 \\
\hline - Perokok & 10 & 52,6 & 9 & 47,4 & & & & & & & & \\
\hline \multicolumn{13}{|l|}{ HADS ansietas } \\
\hline - Perbaikan & 26 & 74,3 & 9 & 25,7 & $0,031^{*}$ & 11,56 & 1,14 & 117,43 & 0,229 & 4,57 & 0,38 & 54,45 \\
\hline - Tidak perbaikan & 2 & 28,6 & 5 & 71,4 & & & & & & & & \\
\hline \multicolumn{13}{|l|}{ HADS depresi } \\
\hline - Perbaikan & 25 & 75,8 & 8 & 24,2 & $0,027^{¥}$ & 7,81 & 1,26 & 48,36 & 0,724 & 1,58 & 0,13 & 19,62 \\
\hline - Tidak perbaikan & 2 & 28,6 & 5 & 71,4 & & & & & & & & \\
\hline
\end{tabular}

${ }^{*}$ Fisher's exact; ${ }^{\text {E}}$ Pearson Chi-square; NIHSS: National Institute of Health Stroke Scale; HADS: Hospital Anxiety and Depression Scale; RO: rasio Odds; IK: interval kepercayaan; $\operatorname{Exp}(\mathrm{B})$ : exponen; (B); Min: minimal; Max: maximal.

Ansietas dan depresi pada pasien stroke sering terjadi dan berpengaruh terhadap luaran klinis neurologis. Penelitian yang memublikasikan problem emosional pada stroke akut masih sedikit. Walaupun diagnosis ansietas dan depresi tidak memungkinkan pada fase ini, tetapi pengenalan gejala ansietas dan depresi penting untuk pasien stroke akut karena berhubungan dengan luaran klinis neurologis. ${ }^{23}$

Suara lantunan Al-Qur'an memiliki frekuensi $0,5-3,0 \mathrm{~Hz}$, yang berarti frekuensi tersebut memiliki pengaruh terhadap gelombang delta. Suara lantunan Al-Qur'an meningkatkan gelombang delta lebih dari $50 \% .{ }^{6}$ Gelombang delta adalah gelombang yang erat kaitannya dengan proses relaksasi tubuh. Semakin tinggi gelombang delta yang dihasilkan dalam otak, semakin tinggi pula tingkat relaksasi yang didapat oleh seseorang. ${ }^{6}$

Bacaan ayat-ayat Al-Qur' an dapat mengakibatkan perubahan psikologis yang sangat besar. Penurunan depresi, kesedihan, ketenangan jiwa, menangkal berbagai macam penyakit merupakan pengaruh umum yang dirasakan pada mereka yang mendengarkan Al-Qur'an. Membacakan Al-Qur'an dengan tartil mendapatkan ketenangan sampai $65 \%$ dibandingkan ketika mendengarkan bacaan bahasa Arab yang bukan dari Al-Qur'an didapatkan ketenangan hanya $35 \% .{ }^{24}$

Mahjoob pada penelitian terhadap pasien yang mendapat perlakuan berupa mendengarkan Al-Qur'an didapatkan perbedaan yang bermakna pada status kesehatan mental (a standard mental health questionnaire) antara sebelum dan setelah mendengarkan resitasi Al-Qur'an. Penelitian ini sesuai dengan penelitian sebelumnya dimana AlQur'an secara bermakna berpengaruh dengan ansietas. Babamohamad dalam penelitiannya tentang efek mendengarkan Al-Qur'an terhadap perbaikan gejala depresi pada pasien yang sedang menjalani hemodialisis didapatkan hasil yang bermakna terhadap penurunan gejala depresi. ${ }^{25}$ 
Pada penelitian ini, memperdengarkan murottal Al-Qur'an tidak berpengaruh terhadap perbaikan gangguan depresi. Pada penelitian Mahjoob, lama perlakuan mendengarkan Al-Qur'an adalah 15 menit setiap hari selama 2 bulan. Penelitian Babamohamad mendengarkan Al-Qur'an dilakukan selama 20 menit tiga kali seminggu selama 1 bulan. Pada penelitian ini lama mendengarkan Al-Qur'an hanya 7 hari. Lama waktu pemberian perlakuan memberikan hasil yang berbeda terhadap ansietas maupun depresi.

Mendengarkan Al-Qur'an lebih efektif dalam menurunkan kecemasan dibandingkan terapi musik klasik. Faradisi dalam penelitiannya terhadap kecemasan pasien preoperasi fraktur ekstremitas mendapatkan bahwa terapi musik klasik dan murottal efektif dalam menurunkan kecemasan pasien sebelum operasi, dimana mendengarkan murottal lebih efektif menurunkan kecemasan dibandingkan musik klasik. ${ }^{26}$ Pada penelitian ini, efektivitas pemberian murottal tidak dibandingkan dengan terapi suara lainnya sehingga penelitian selanjutnya yang membandingkan murottal dengan musik klasik dengan populasi pasien di Indonesia menarik untuk diteliti.

Terdapat perbedaan skor NIHSS yang bermakna antara subjek diperdengarkan murottal Al-Qur'an dan kelompok kontrol. Analisis bivariat menunjukkan terdapat hubungan yang bermakna antara murottal Al-Qur'an yang diperdengarkan dengan perubahan skor NIHSS pada pasien stroke iskemik akut. Analisis bivariat juga menunjukkan terdapat hubungan yang bermakna antara perubahan skor HADS ansietas dan depresi dengan perubahan skor NIHSS pasien stroke iskemik akut. Pada analisis multivariat didapatkan variabel yang berhubungan dengan perubahan NIHSS adalah memperdengarkan murottal Al-Qur'an.

Kecemasan dan depresi pada pasien stroke sering terjadi dan berpengaruh terhadap luaran klinis neurologis. Bacaan ayat suci Al-Qur'an memiliki nilai religiositas dan spiritualitas yang tinggi, sehingga dapat digunakan sebagai teknik relaksasi spiritual untuk mendapatkan ketenangan jiwa. Pada pasien yang mendapatkan perlakuan berupa memperdengarkan murottal Al-Qur'an didapatkan perbaikan skor ansietas dan perbaikan luaran klinis neurologis/NIHSS. Pada penelitian ini perbaikan luaran klinis neurologis dikarenakan pasien mengalami perbaikan skor cemas setelah diperdengarkan murottal Al-Qur'an.

Penelitian ini memiliki keterbatasan diantaranya belum dilakukan pemeriksaan pengaruh memperdengarkan murottal Al-Qur'an terhadap luaran klinis neurologis stroke iskemik akut melalui fungsi lain seperti antiinflamasi, kadar kortisol serum, ataupun melalui unsur-unsur religiositas, dan spiritualitas. Penelitian perlakuan hanya selama 7 hari sehingga diperlukan durasi yang lebih lama supaya didapatkan hasil yang lebih baik dan belum dilakukan pemeriksaan EEG untuk mengetehui efek lantunan Al-Qur'an terhadap gelombang otak. Penelitian ini juga belum membandingkan antara pemberian murottal dengan terapi suara yang lainnya seperti musik.

\section{KESIMPULAN}

Memperdengarkan murottal Al-Qur'an pada pasien stroke iskemik akut berpengaruh terhadap perbaikan gangguan ansietas dan luaran klinis neurologis. Memperdengarkan murottal AlQur'an pada pasien stroke iskemik akut mempunyai kemungkinan perbaikan luaran klinis neurologis sebesar 9,025 kali dibanding kontrol.

\section{DAFTAR PUSTAKA}

1. Khan N, Ahmad NB, Beg AH, Fakheraldin MAI, Alla ANA, Nubli M. Mental and spiritual relaxation by recitation of the holy Qur'an. Dalam: Proceeding of the 2010 Second International Conference on Computer Research and Development; 7-10 Mei 2010; Kuala Lumpur, Malaysia. New Jersey: IEEE; 2010. h. 863-7.

2. Giaquinto S, Sarno S, Armi VD, Spiridigliozzi C. Religious and spiritual beliefs in stroke rehabilitation. Clin Expr Hypertention. 2010;32(6):329-34.

3. Tartaro J, Luecken LJ, Gunn HE. Exploring heart and soul: effects of religiosity/spirituality and gender on blood pressure and cortisol stress responses. 2005;10(6):753-66.

4. Okada K, Iwahara S, Kusama Y, Atarashi H. Spiritual activation in very elderly individuals assessed as heart rate variability and plasma IL/10/IL-6 ratios. 2011;52(5):299-303. 
5. Shattuck EC, Muehlenbein MP. Religiosity/ spirituality and physiological markers of health. J Relig Health. 2018;2018:1-20.

6. Abdurrochman A, Wulandari RD, Fatimah N. The comparison of classical music, relaxation music and the Qur'anic recital: an AEP study. Paper presented at The 2007 Regional Symposium on Biophysics and Medical Physic, Bogor Agricultural University IPB; Bogor, Indonesia; 27-30 November 2007.

7. Mahjoob M, Nejati J. The effect of holy Qur'an voice on mental health. J Relig Health. 2016;55(1):38-42.

8. Hematti S, Baradaran-Ghahfarokhi M, KhajooeiFard R, Mohammadi-Bertiani Z. Spiritual wellbeing for increasing life expectancy in palliative radiotherapy patients: a questionnaire. J Reli Heal. 2015;54(5):1563-72.

9. Frishkopf M. Mediated Qur'anic recitation and the contestation of islam in contemp. Dalam: Nooshin L, editor. Music and the play of power in the middle east, North Africa and Central Asia. London: Ashgate Publishing; 2009. h. 75-110.

10. Murtisari Y, Ismonah S. Pengaruh pemberian terapi musik klasik terhadap penurunan tingkat depresi pada pasien stroke nonhemoragik di RSUD Salatiga. JIKK. 2014.

11. Haryanto, Kardiatun T, Surtikanti AM. Comparison of murottal and music therapy against people with hypertention. J Keperawatan dan Kesehat. 2014;II(2):12-25.

12. Julianto V, Dzulqaidah RP, Salsabila SN. Pengaruh mendengarkan murattal Al-Qur'an terhadap peningkatan kemampuan konsentrasi. Psympathic: J Ilm Psikol. 2014;1(2):120-9.

13. Juliana. Pengaruh murottal Al-Qur'an terhadap penurunan tingkat insomnia pada lansia. STIKES Ngudi Waluyo Ungaran; 2014.

14. Pusat Penelitian dan Pengembangan Departemen Kesehatan RI. Riset kesehatan dasar 2013; 2013.

15. Guo Y, Li P, Guo Q, Shang K, Yan D, Du S, dkk. Pathophysiology and biomarkers in acute ischemic stroke-a review. Trop J Pharm Res. 2013;12(6):1097105.
16. ICSI. Diagnosis and initial treatment of ischemic stroke health care guideline and order sets: diagnosis and initial treatment of ischemic stroke screening (ambulatory) algorithm. Inst Clin Systems Improv. 2012.

17. Neidert S, Katan M, Schuetz P, Fluri F, Ernst A, Bingisser R, dkk. Anterior pituitary axis hormones and outcome in acute ischaemic stroke. J Intern Med. 2011;269:420-32.

18. Mracsko E, Liesz A, Karcher S, Zorn M, Bari F, Veltkamp R. Brain, behavior, and immunity differential effects of sympathetic nervous system and hypothalamic-pituitary-adrenal axis on systemic immune cells after severe experimental stroke. Brain Behav Immun. 2014;41:200-9.

19. Jayne A, Gray P, Deborah S, Alasdair S, Joseph M. Cortisol levels and the severity and outcomes of acute stroke: a systematic review. J Neurol. 2014;5(1):1-10.

20. Hackett ML, Kohler S, Brien JTO, Mead GE. Neuropsychiatric outcomes of stroke. Lancet Neurol. 2014;4422(14):1-10.

21. Weimar C, Kraywinkel K, Ziegler A, Diener HC. Age and national institutes of health stroke scale score within 6 hours after onset are accurate predictors of outcome after cerebral ischemia development and external validation of prognostic models. Stroke. 2004;35:158-62.

22. Corso G, Bottacchi E, Tosi P, Caligiana L, Lia C, Morosini MV, dkk. Outcome predictors in first-ever ischemic stroke patients: a population-based study. Int Sch Res Not. 2014;2014(12):904647.

23. Fure B, Wyller TB, Engedal K, Thommessen B. Emotional symptoms in acute ischemic stroke. Int $\mathrm{J}$ Geriatr Psychiatry. 2006;21(4):382-7.

24. Faradisi F. Efektivitas terapi murotal dan terapi musik klasik terhadap penurunan tingkat kecemasan pasien pra operasi di pekalongan. JIK. 2012;5(2):1-11.

25. Santalucia P, Pezzella FR, Sessa M, Monaco S, Torgano G, Anticoli S, dkk. Sex differences in clinical presentation, severity and outcome of stroke: Results from a hospital-based registry. Eur J Intern Med. 2013;24(2):167-71. 